INFLAMMATORY BOWEL DISEASE

\title{
Reduction in diversity of the colonic mucosa associated bacterial microflora in patients with active inflammatory bowel disease
}

\author{
S J Ott, M Musfeldt, D F Wenderoth, J Hampe, O Brant, U R Fölsch, K N Timmis, S Schreiber
}

Gut 2004;53:685-693. doi: 10.1136/gut.2003.025403

Background and aims: The intestinal bacterial microflora plays an important role in the aetiology of inflammatory bowel disease (IBD). As most of the colonic bacteria cannot be identified by culture techniques, genomic technology can be used for analysis of the composition of the microflora.

Patients and methods: The mucosa associated colonic microflora of 57 patients with active inflammatory bowel disease and 46 controls was investigated using 16S rDNA based single strand conformation polymorphism (SSCP) fingerprint, cloning experiments, and real time polymerase chain reaction (PCR).

See end of article for authors' affiliations Results: Full length sequencing of 1019 clones from $16 \mathrm{~S}$ rDNA libraries $(n=3)$ revealed an overall bacterial diversity of 83 non-redundant sequences-among them, only 49 known bacterial species. Molecular epidemiology of the composition of the colonic microflora was investigated by SSCP. Diversity of the microflora in Crohn's disease was reduced to $50 \%$ compared with controls (21.7 v 50.4; $\mathrm{p}<0.0001)$ and to $30 \%$ in ulcerative colitis $(17.2 \vee 50.4 ; \mathrm{p}<0.0001)$. The reduction in diversity in inflammatory bowel disease was due to loss of normal anaerobic bacteria such as Bacteroides species, Eubacterium species, and Lactobacillus species, as revealed by direct sequencing of variable bands and confirmed by real time PCR. Bacterial diversity in the Crohn's group showed no association with CARDI5/ NOD2 status.

Correspondence to: Department, University Hospital SchleswigHolstein, Campus Kiel Schittenhelmstr, 12, 24105 Kiel, Germany; s.schreiber@mucosa.de

Accepted for publication 10 November 2003

Conclusions: Mucosal inflammation in inflammatory bowel disease is associated with loss of normal anaerobic bacteria. This effect is independent of NOD2/CARD15 status of patients.

A nimal models of inflammatory bowel disease (IBD) suggest that manifestation of intestinal inflammation is critically dependent on the presence of the intestinal microflora as an important trigger. Alterations of the composition of the intestinal microflora can significantly alter host immunity and the course of mucosal inflammation. ${ }^{1-3}$ Genetic susceptibility has been clearly documented in both Crohn's disease (CD) and ulcerative colitis (UC)..$^{4-6}$ Analysis of the composition of the intestinal microflora in genetically susceptible individuals appears therefore important. ${ }^{7-10}$ The exact role of the intestinal microflora in IBD has not yet been defined. Due to the similarities in the features of IBD and classic infectious enteritis and Johne's disease, a variety of microbial agents have been proposed as aetiological factors in IBD in the past decades. ${ }^{11-17}$ However, no specific pathogen has been consistently identified and independently confirmed.

Most of the colonic bacteria, such as Escherichia coli or some Bacteroides species, are commensals and not pathogens. For example, the detrimental effects of Bacteroides vulgatus in animal models of IBD seem to be dependent on the underlying model. ${ }^{18-22}$ Experimental data and clinical observations suggest an important role of the complex intestinal microflora in the development of mucosal inflammation. ${ }^{23}$ For example, diversion of the faecal stream is associated with distal improvement in patients with $\mathrm{CD}$, and relapse consistently occurs on restoration of the faecal stream. ${ }^{24}$ UC patients who undergo ileal pouch-anal anastomosis surgery may develop mucosal inflammation after recolonisation of the ileal pouch by colonic bacteria through faecal stasis. ${ }^{25}$ Certain probiotic microorganisms of the normal intestinal microflora such as Lactobacillus, Bifidobacterium, and Saccharomyces have been shown to be effective in remission maintenance of UC, thereby suggesting anti-inflammatory effects. $^{26-31}$
The composition of the normal intestinal microflora was investigated using classical bacterial culture of faecal samples in a comprehensive study more than 15 years ago. ${ }^{32}$ However, culture based methods identify only $10-40 \%$ of bacteria of a complex bacterial community such as the faecal microflora, ${ }^{33-38}$ therefore new attempts using current DNA based methodologies are warranted. Analysis of variability in the 16S rDNA provides a culture independent approach to bacterial taxonomy. ${ }^{39-41}$ 16S rDNA has been targeted previously to analyse bacterial communities of the intestine ${ }^{34} 42-48$ and to investigate the dominant taxa using oligonucleotide hybridisation, real time polymerase chain reaction (PCR), and fluorescent in situ hybridisation. ${ }^{49-51}$ Single strand conformation polymorphism (SSCP) analysis and other genetic fingerprint techniques using universal primers have been shown to be powerful tools in determining microbial diversity in complex samples. ${ }^{52-55}$ Because IBD is a disorder of mucosal inflammation, the mucosa associated microflora seems of peculiar relevance to the disease process. ${ }^{44} 51$ The composition of the mucosal and mid stream/faecal microflora has been shown to be significantly different. ${ }^{45}$ For a better understanding of IBD, characterisation of the mucosa associated bacterial microflora is therefore required.

The aim of this study was to compare the bacterial composition and to identify differences in bacteria of the mucosa associated intestinal microflora of patients with

Abbreviations: CAl, clinical activity index; $C D, C$ rohn's disease; CDAl, Crohn's disease activity index; IBD, inflammatory bowel disease; OTU, operational taxonomic unit; SNP, single nucleotide polymorphism; SSCP, single strand conformation polymorphism; ssDNA, single stranded DNA; UC, ulcerative colitis; UPGMA, unweighted pair group method with arithmetic mean 
active IBD and controls using cloning experiments, SSCP fingerprinting, and real time PCR in biopsy samples. We showed that bacterial diversity in active IBD was reduced in comparison with controls. Species lacking in disease were members of the normal anaerobic microflora.

\section{MATERIALS AND METHODS Patients}

Twenty six patients with CD, 31 patients with active ulcerative colitis UC, and 46 controls were studied. Diagnosis of IBD was made in accordance with established criteria. ${ }^{57}{ }^{58}$ Disease activity was assessed by the CD activity index (CDAI) for CD and the clinical activity index (CAI) for UC. All patients with IBD were in an active phase of disease (CDAI $>150$ in the CD group and CAI $>4$ in the UC group, respectively). Ten untreated patients with active Crohn's disease (CDAI > 150) from the placebo group of a clinical IBD trial were also included. These patients were followed up after six weeks, showing no significant clinical or endoscopic improvement of disease activity. A non-inflammatory control group included healthy individuals (no suspicious macroscopic or histological findings, $n=20$ ), patients with diverticulosis $(n=7)$, and patients with polyps $(n=4)$. To rule out the effects of diarrhoea or general inflammation on bacterial diversity, a second control group was investigated comprising patients with other forms of intestinal mucosal inflammation and diarrhoea (undetermined colitis $\mathrm{n}=2$, unclear diarrhoea $\mathrm{n}=5$, infectious colitis $\mathrm{n}=7$, and radiation colitis $\mathrm{n}=1$ ). In all groups, biopsies were taken from different segments of the colon. Patient characteristics are shown in table 1. The probands received no antibiotic therapy at the time of investigation and in the last six month. Biopsies from IBD patients were taken from sites of macroscopic inflammation. The study was approved by the institutional review board. All patients gave written informed consent prior to colonoscopy.

\section{Treatment of biopsies and DNA extraction}

Biopsy specimens were immediately snap frozen in liquid nitrogen. Biopsies were incubated with $200 \mu \mathrm{l}$ TL-buffer and $25 \mu \mathrm{l}$ proteinase $\mathrm{K}$ at $55^{\circ} \mathrm{C}$ for two hours (PeqLab, Erlangen, Germany). DNA was extracted with the FastDNA SPIN Kit for Soil after mechanical homogenisation (FastPrep FP120 instrument) according to the manufacturer's instructions (both BIO101; Carlsbad, California, USA). DNA concentrations were determined using PicoGreen (dsDNA Quantification Kit; Molecular Probes, Leiden, the Netherlands).

\section{Clone libraries}

Clone libraries from three patients, a healthy control, a patient with $\mathrm{CD}$, and a patient with UC were generated. A single biopsy from the sigma of each patient was used for this experiment and DNA was extracted separately. The full length 16S rDNA was amplified with generic primers covering most intestinal bacterial species (table 2). The reaction mixture contained $10 \times$ PCR buffer, $15 \mathrm{mM} \mathrm{MgCl}_{2}$ (Qiagen, Hilden, Germany), a $0.2 \mu \mathrm{M}$ concentration of each primer (Eurogentec, Seraing, Belgium), a $0.2 \mu \mathrm{M}$ concentration of each deoxynucleoside triphosphate (Qiagen), I U DNA Taq polymerase (Qiagen, Hildesheim, Germany), and 100ng of sample DNA using the following PCR protocol: $95^{\circ} \mathrm{C}$ for five minutes, 25 cycles of $95^{\circ} \mathrm{C}$ for 30 seconds, $60^{\circ} \mathrm{C}$ for one minute, and $72^{\circ} \mathrm{C}$ for three minutes.

DNA was cloned into competent Escherichia coli cells using the pCR 2.1 TOPO TA Cloning Kit (Invitrogen, Karlsruhe, Germany). Plasmid DNA from overnight cultures was prepared with the QIAprep 96 Turbo Miniprep Kit (Qiagen). Sequencing of the inserts was performed on an ABI PRISM 3700 DNA analyser in a final volume of $10 \mu \mathrm{l}$ using $1 \mu \mathrm{l}$ ABI PRISM BigDye (both Applied Biosystems, Foster City, California, USA), a 1.6 $\mu \mathrm{M}$ concentration of each primer using the following protocol: $90^{\circ} \mathrm{C}$ for three minutes, 25 cycles of $95^{\circ} \mathrm{C}$ for 40 seconds, $55^{\circ} \mathrm{C}$ for 40 seconds, and $60^{\circ}$ for four minutes. Primer characteristics are indicated in table 2. Alignment and assembly of partial sequences were performed using the Phred/Phrap/Consed software package (Genome Software Development, University of Washington at Seattle, Washington, USA). Specific bacteria were identified by NCBI BLAST analysis using search results of at least 97\% similarity (NCBI BLAST, http://www.ncbi.nlm.nih.gov/ BLAST/).

\section{SSCP analysis}

SSCP analysis was performed for all patients included in this study. For initial PCR, the two conserved primers Com- 1 and Com2-Ph were used (table 2). The reverse primer Com2-Ph contained a 5'-terminal phosphate group. The fragment size of the amplified V4 and V5 region of the 16S rDNA was $390 \mathrm{bp}$. Initial PCR, preparation of single strand DNA, and silver staining of SSCP gels were performed according to Schwieger and Tebbe. ${ }^{52}$ The amount of single stranded DNA (ssDNA) was measured with laser induced fluorescence (OliGreen Quantitation Kit; Molecular Probes) on a fluorescence microplate reader (SpectraFluorPlus, Tecan, Crailsheim, Germany) according to the manufacturer's instructions. The amount of ssDNA was adjusted to $200 \mathrm{ng}$ per lane prior to SSCP analysis. To identify the bacteria correlated to the bands, selected bands from the polyacrylamide gel after silver staining were excised with sterile scalpels and processed as described elsewhere. ${ }^{52} 59$ The sequencing reaction was performed on an ABI PRISM 3700

\begin{tabular}{|c|c|c|c|c|}
\hline & $\begin{array}{l}\text { Non-inflammatory } \\
\text { controls* }(n=31)\end{array}$ & $\begin{array}{l}\text { Inflammatory } \\
\text { controlst }(n=15)\end{array}$ & $C D(n=26)$ & $U C(n=31)$ \\
\hline Mean age $(y)$ & $52(26-74)$ & $50(20-82)$ & $35(16-56)$ & $44(23-74)$ \\
\hline $\operatorname{Sex}(M / F)$ & $10 / 21$ & $6 / 9$ & $9 / 17$ & $18 / 13$ \\
\hline \multicolumn{5}{|l|}{ Localisation } \\
\hline Right colon & 29 & 6 & 15 & 9 \\
\hline Leff colon & 2 & 9 & 11 & 22 \\
\hline \multicolumn{5}{|l|}{ Treatment } \\
\hline Corticosteroids & 0 & 0 & 9 & 8 \\
\hline Purine analogues & 0 & 0 & 2 & 1 \\
\hline 5-ASA & 0 & 0 & 2 & 16 \\
\hline Specific disease activity & - & - & CDAI $>150$ & $\mathrm{CAl}>4$ \\
\hline
\end{tabular}


Table 2 Polymerase chain reaction (PCR) and sequencing primers used in this study

\begin{tabular}{|c|c|c|c|c|c|}
\hline Application & Primer & Direction & Position* & Sequence $\left(5^{\prime}-3^{\prime}\right)$ & Ref \\
\hline $\begin{array}{l}\text { PCR/sequencing } \\
\text { Sequencing } \\
\text { Sequencing } \\
\text { Sequencing } \\
\text { Sequencing } \\
\text { Sequencing } \\
\text { PCR/sequencing } \\
\mathrm{SSCP} / \text { sequencing } \\
\mathrm{SSCP} / \text { sequencing }\end{array}$ & $\begin{array}{l}\text { TPU1 } \\
\text { TPU2 } \\
\text { M13 (20) } \\
\text { M13 (40) } \\
\text { TPU5 } \\
\text { 1000R } \\
\text { RTU8 } \\
\text { Com1 } \\
\text { Com2-Ph } \ddagger\end{array}$ & $\begin{array}{l}\text { Forward } \\
\text { Forward } \\
\text { Forward } \\
\text { Reverse } \\
\text { Forward } \\
\text { Reverse } \\
\text { Reverse } \\
\text { Forward } \\
\text { Reverse }\end{array}$ & $\begin{array}{l}8-27^{*} \\
334-53^{*} \\
389-404 \dagger \\
205-21 \dagger \\
906-26^{*} \\
1100-15^{*} \\
1522-41^{*} \\
519-36^{*} \\
907-26^{*}\end{array}$ & $\begin{array}{l}\text { AGAGTTTGATCATGGCTCAG } \\
\text { CCAGACTCCTACGGGAGGCA } \\
\text { GTCGTGACTGGGAAAAC } \\
\text { AACAGCTATGACCATG } \\
\text { AAACTCAAATGAATTGACGG } \\
\text { GGGTIGCGCTCGTIGC } \\
\text { AAGGAGGTGATCCAACCGCA } \\
\text { CAGCAGCCGCGGTAATAC } \\
\text { CCGTCAATTCCTTGAGTT }\end{array}$ & $\begin{array}{l}\text { von Wintzingerode }{ }^{78} \\
\text { von Wintzingerode } \\
\text { Guttman }^{79} \\
\text { Guttman }^{79} \\
\text { von Wintzingerode } \\
\text { von Wintzingerode } \\
\text { von Wintzingerode } \\
\text { Schwieger } \\
\text { Schwieger }^{52}\end{array}$ \\
\hline
\end{tabular}

DNA analyser using $2 \mu \mathrm{l}$ of digested PCR product, as described above. The sequences were analysed and aligned using the Sequencher software package (Gene Codes Corp., Ann Arbor, Michigan, USA). Fragments were identified by NCBI blast search (BLAST, http://www.ncbi.nlm.nih.gov/ BLAST/).

\section{Gel analysis}

For image analysis, GelCompare II software was used (Applied Maths, Kortrijk, Belgium). Bacterial diversity was calculated as number of bands according to Seksik and colleagues $^{46}$ and as weighted diversity scores according to Shannon and Weaver. ${ }^{60}{ }^{61}$ Cluster analysis and calculation of similarity scores between the different banding patterns were performed using Pearson's correlation and the unweighted pair group method with arithmetic mean (UPGMA) dendrogram type. ${ }^{62}$

\section{Real time PCR standard curves}

For standardisation of real time PCR, different bacterial strains were cultivated (including Enterobacter cloacae and Bacteroides fragilis for specific standard curves). After adjusting bacterial concentration (Neubauer chambers), bacterial cells were centrifuged $(8000 \mathrm{~g}, 10$ minutes at room temperature) and pellets frozen at $-20^{\circ} \mathrm{C}$. DNA was isolated from bacterial species as described above. Serial dilutions of bacterial DNA over several log ranks were performed to generate a standard curve for real time PCR. The total number of cells was interpolated from the averaged standard curve, as described elsewhere. ${ }^{63}$

\section{Real time PCR}

Amplification and detection were carried out on an ABI PRISM 7700 Sequence Detector with TaqMan Universal PCR $2 \times$ Master Mix (Applied Biosystems), using primer $(0.4 \mu \mathrm{M})$, probe $(0.2 \mu \mathrm{M})$, and $1 \mathrm{ng} / \mathrm{l} 00 \mathrm{ng}$ of sample DNA (universal/ specific probe) in a final volume of $20 \mu \mathrm{l}$ per reaction using an initial hold of $50^{\circ} \mathrm{C}$ for two minutes to activate No Amp Erase UNG, a hold of $95^{\circ} \mathrm{C}$ for 10 minutes to activate AmpliTaq Gold Polymerase, followed by 50 cycles for 30 seconds, $60^{\circ} \mathrm{C}$ for one minute, and $72^{\circ} \mathrm{C}$ for three minutes. (For probe characteristics see table 3.) The conserved primers TPUl and RTU8 used for real time PCR are indicated in table 2 .

\section{CARD 15/NOD2 genotyping}

We used $3 \mathrm{ng}$ in each reaction. DNA for the genotyping experiment was extracted from mucosal biopsies, as described above, or from EDTA blood, as previously described. ${ }^{4}$ Mutations were assayed with Taqman (Applied Biosystems), as described previously. ${ }^{44}$ We investigated the three major functional variants of CARD15/NOD2-SNP8,
SNP12, and SNP13. The primers and probes used for genotyping and the single nucleotide polymorphisms (SNPs) are described elsewhere. ${ }^{65} 66$

\section{Data analysis}

All data are expressed as means (SEM). Comparisons were made using the Student's $t$ test for variables with a normal distribution, and otherwise using Wilcoxon's test. A p value of $<0.05$ was considered statistically significant.

\section{RESULTS}

\section{Clone libraries of full length 165 rDNA}

Three full length 16S rDNA libraries from mucosal biopsies from CD, UC, and a normal control were established. A total of 1019 clones were fully sequenced to investigate the overall diversity of the intestinal microflora (controls 324 clones; CD 344 clones; UC 351 clones). The identified operational taxonomic units (OTUs) from all three samples are listed in table 4. Among the 83 non-redundant clones, 49 sequences could be assigned to known bacterial species. Approximately $30 \%$ of all OTUs were bacteria that are not further characterised in nucleotide databases or represent potentially new species. Most of the other OTUs were of a previously described intestinal origin but a relevant part derives from the oral mucosa, such as some Streptococcus species, Dialister species, and Actinomyces species. The main bacterial groups were Streptococcus species (34\%), Ruminococcus species (22\%), Escherichia (12.8\%), and Clostridium species (6.5\%). Only small proportions of Eubacterium species $(0.1 \%)$, Fusobacterium species (1.1\%), Peptostreptococcus species $(0.2 \%)$, and Enterobacter species (1.1\%) were detected.

\section{Bacterial profiles as assessed by SSCP analysis}

A dendrogram of a randomly assigned subset of controls $(n=10), C D$ patients $(n=10)$, and UC patients $(n=10)$ is shown in fig 1 . Patients with IBD clustered separately from normal controls using Pearson's correlation and the UPGMA algorithm. Interestingly, 16S rDNA based bacterial profiles of CD and UC patients did not differ significantly as both groups of samples showed mixed clusters (fig 1). To assess the effect of disease independent variables on clustering, separate analysis for localisation (for example, the anatomical site of sampling), age, and medication were performed. No significant association of these factors with the composition of the intestinal microflora was observed (data not shown).

\section{Bacterial diversity and composition of bacterial microflora}

Formal analysis of biodiversity in the three patient cohorts was conducted (fig 2). The mean diversity of the noninflammatory control group, indicated as number of bands (according to Seksik and colleagues ${ }^{46}$ ) of the SSCP profiles, 


\begin{tabular}{|c|c|c|c|c|c|}
\hline Probe & Specificity & Position & Dye & Sequence $\left(5^{\prime}-3^{\prime}\right)$ & Reference \\
\hline $\begin{array}{l}\text { UNI } \\
\text { ENTER } \\
\text { BACT }\end{array}$ & $\begin{array}{l}\text { Eubacteria } \\
\text { Enterobacteriaceae } \\
\text { Bacteroides, Prevotella, } \\
\text { Porphyromonas }\end{array}$ & $\begin{array}{l}321-37 \\
1418-32 \\
1081-97\end{array}$ & $\begin{array}{l}\text { VIC } \\
\text { FAM } \\
\text { FAM }\end{array}$ & $\begin{array}{l}\text { ACTGAGACACGGTCCA } \\
\text { CITTGCAACCCACT } \\
\text { CACTTAGCCGACACCT }\end{array}$ & $\begin{array}{l}\text { von Wintzingerode }{ }^{78} \\
\text { Modified from Sghir } \\
\text { Dore }^{89}\end{array}$ \\
\hline
\end{tabular}

was 50.4 (SD 14.7) compared with 21.7 (10.4) in the CD group $(\mathrm{p}<0.0001)$ and $17.2(4.4)$ in the UC group $(\mathrm{p}<0.0001)$ (fig 2). Thus the mean biodiversity of healthy controls is twofold that of CD patients and threefold that of UC patients. The cohort with inflammatory controls was analysed separately and showed a complex microflora with a total number of bands of 45.4 (SD 7.73), similar to that of noninflammatory controls $(\mathrm{p}<0.001$ compared with CD and UC). Furthermore, weighted diversity indices were calculated according to Shannon and Weaver, considering not only number of bands but also their intensity. ${ }^{60}{ }^{61}$ The corresponding weighted diversity values showed the same tendency. For the non-inflammatory control group, a mean diversity score of 1.44 (SD 0.16) compared with 1.2 (SD 0.23) in the CD and 1.16 (SD 0.14) in the UC group was calculated. The differences were also statistically significant $(p<0.0001)$. The diversity index for the inflammatory control group (1.51, SD 0.075) was higher compared with non-inflammatory

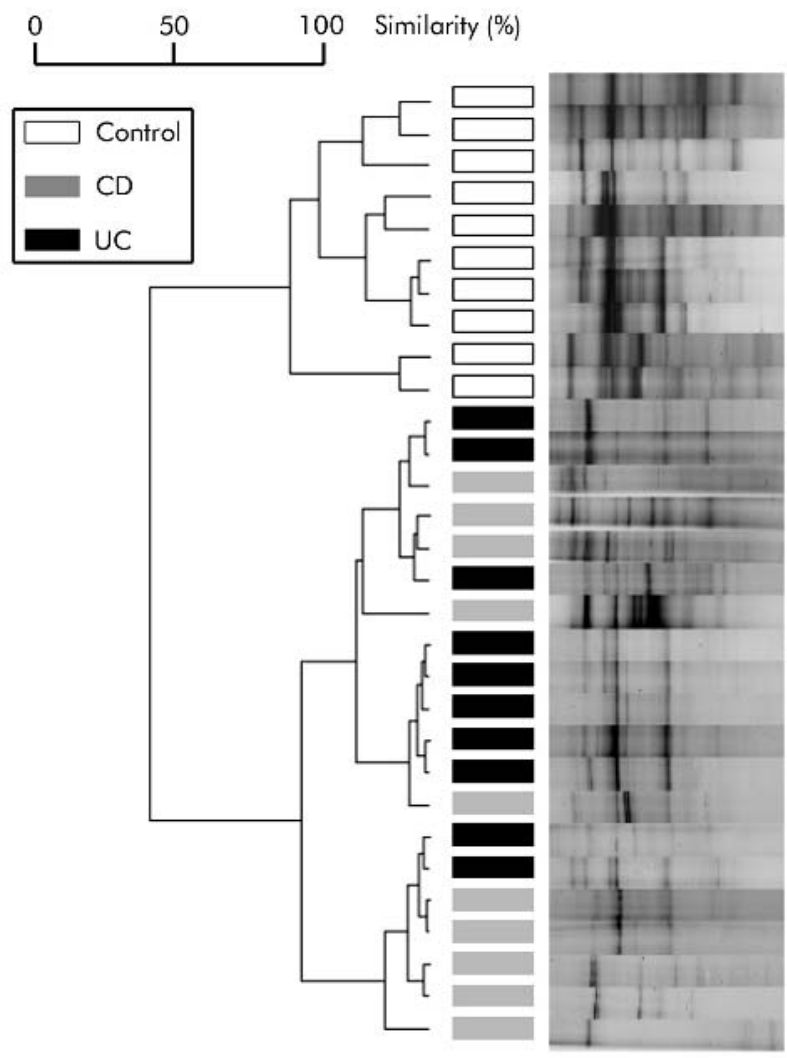

Figure 1 Dendrogram and normalised single strand conformation polymorphism profiles obtained from a cluster analysis of 10 randomly assigned profiles from controls, Crohn's disease (CD), and ulcerative colitis (UC) patients. Patients are marked with bars in different grey scales, as indicated in the legend. Separation of controls and disease groups is clearly visible, while CD and UC patients show mixed clusters. For cluster analysis, Pearson's correlation and the unweighted pair group method with arithmetic mean algorithm were applied.

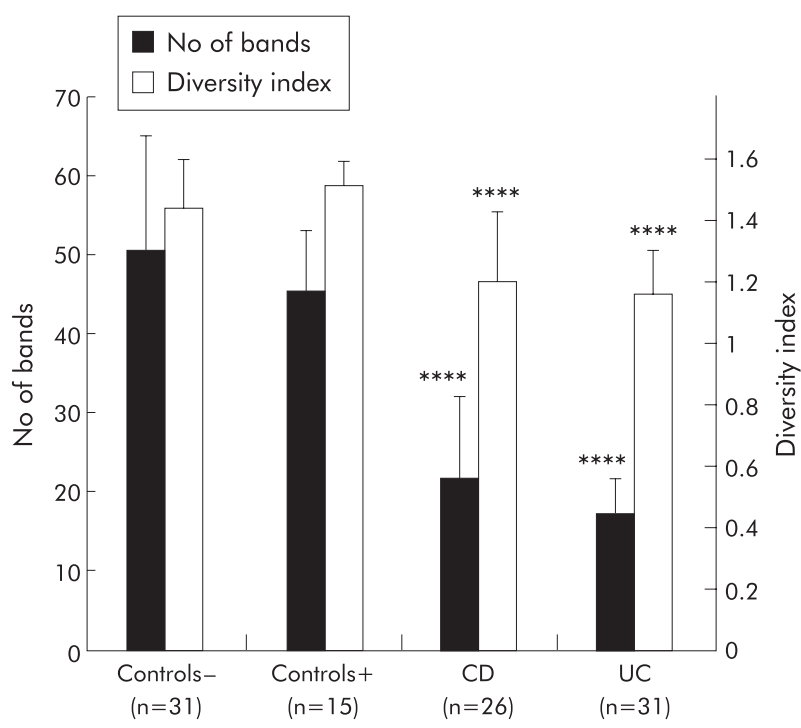

Figure 2 Band numbers and bacterial diversity obtained from single strand conformation polymorphism profiles of inflammatory bowel disease patients (Crohn's disease (CD) and ulcerative colitis (UC)), non-inflammatory controls (controls-), and inflammatory controls (controls+). For each group, the mean numbers of bands (SD) are shown. Diversity of the controls was significantly higher compared with the disease groups. The weighted diversity scores (SD) according to Shannon and Weaver ${ }^{60}$ showed the same pattern. Results for comparison of both non-inflammatory and inflammatory controls and CD/UC were statistically significant: ${ }^{* * *} p<0.0001$.

controls but was not significant $(\mathrm{p}<0.001$ compared with $\mathrm{CD}$ and UC). No association of biopsy localisation and age with bacterial diversity was observed (data not shown). A comparison of bacterial diversity with medication in the IBD group showed no significant differences (fig 3).

Comparison between CD and UC patients showed no significant differences but 20 bands were found to be significantly more frequent in the control group compared with IBD patients. Thirteen of 20 bands gave a reproducible signal in the sequencing analysis. Representatives of the mucosa associated microflora, as obtained from the full length (1.6 kb) library sequencing (table 4 ), were compared with SSCP sequences (390 bp). Bacteria characteristics for normal controls were put into the context of selected members of the total intestinal microflora, as obtained from the library sequencing through phylogenetic tree analysis (fig 4). Three distinct clusters are evident: the first cluster includes OTUs of the Bacteroidales/Prevotella group that belong to the abundant anaerobic intestinal microflora. The second cluster shows OTUs that belong to the Firmicutes phylum found to be frequent members of the normal enteric microflora. One of the OTUs was assigned to the Enterobacteriaceae cluster which contains different gut related genera such as Escherichia, Enterobacter, and Serratia. Sequences of the uncultured or unidentified bacteria showed phylogenetic relationships to one of the clusters. 


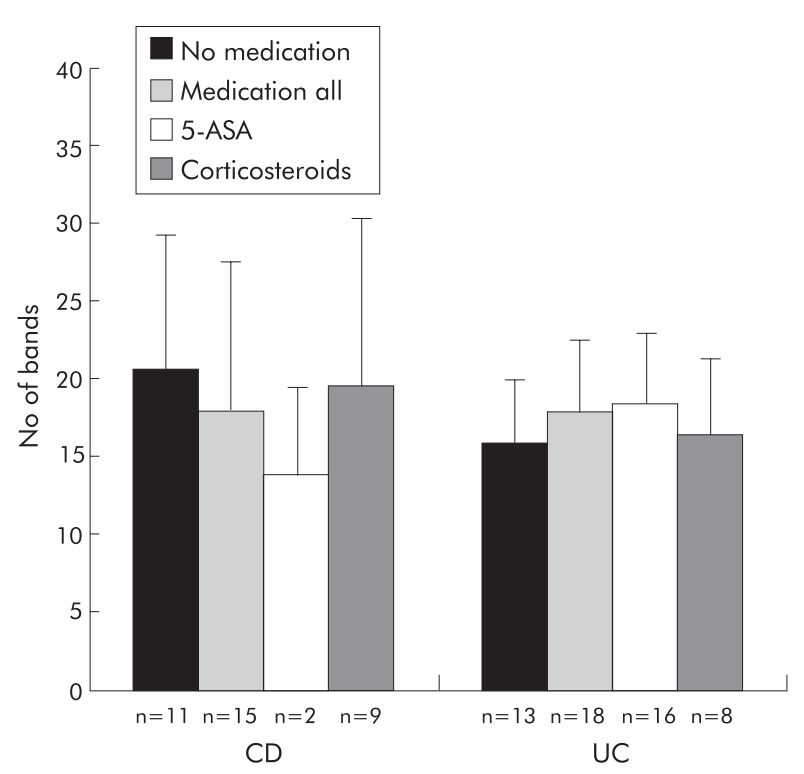

Figure 3 Bacterial diversity, indicated as number of bands versus medication. Four groups were compared: no medication, medication all (including single patients with combined medication), 5-aminosalicyclic acid (5-ASA), and corticosteroids. For each group, the mean (SD) numbers of bands are shown. Differences were not statistically significant.

\section{Quantification of total bacteria and of two major groups of anaerobic bacteria}

To verify the results of the SSCP approach, a 16S based quantitative real time PCR was performed quantifying total bacteria and two major groups of anaerobic bacteria. For the total number of bacterial cells, as detected with the universal probe, no significant differences between controls and CD/UC patients were determined (data not shown). Quantification of Enterobacteriaceae and Bacteroidetes (including Bacteroides sp, Prevotella sp, and Porphyromonas sp) showed a significant reduction in cell numbers in CD/UC patients compared with controls (fig 5). For Bacteroidetes, reductions of $78.12 \%$ $(\mathrm{p}<0.0001)$ in the CD and $76.99 \%(\mathrm{p}<0.0001)$ in the UC group were detected. Enterobacteriaceae sp were decreased by $45.88 \%$ in $C D(p<0.003)$ and by $59.31 \%(p<0.0001)$ in UC patients. Cell numbers were normalised to the total amount of extracted DNA.

\section{Intraindividual variability of intestinal microflora in active CD}

Ten patients in the CD group were re-examined at six weeks after the first examination. Disease was still active in all of them, and biopsies were taken from the same location. Medication had not been changed during the six week period. Diversity after six weeks was lower compared with basal values $(21.5 \vee 15.7)$ but not statistically significant $(p=0.1255)$. Weighted diversity scores showed a similar pattern (fig 6).

\section{Bacterial diversity and CARD15/NOD2 status of patients with Crohn's disease}

Six of the 26 patients with CD $(30 \%)$ carried at least one of the three major SNPs. Bacterial diversity in CARD15/NOD2 positive patients $(n=6)$ was lower compared with nonaffected patients $(n=20)$ but the results were not statistically significant (fig 7). Both indicators of bacterial diversity, number of bands $(18 \vee 22.85 ; \mathrm{p}=0.06)$ and diversity index ( $1.036 v 1.25 ; \mathrm{p}=0.11)$, showed the same tendency.
Table 4 Bacterial operational taxonomic units (OTUs) derived from clone libraries

\begin{tabular}{|c|c|c|}
\hline Bacterial species* & n† & $\%$ \\
\hline \multicolumn{3}{|l|}{ Gram negative aerobic bacteria } \\
\hline Alcaligenes sp & 1 & 0.1 \\
\hline \multicolumn{3}{|l|}{ Gram negative anaerobic bacteria } \\
\hline Veillonella dispar & 1 & 0.1 \\
\hline Veillonella sp oral clone X042 & 1 & 0.1 \\
\hline Fusobacterium nucleatum subsp nucleatum & 3 & 0.3 \\
\hline Dialister sp oral clone BS095 & 4 & 0.4 \\
\hline Dialister pneumosintes & 5 & 0.5 \\
\hline Fusobacterium sp (different clones) & 8 & 0.8 \\
\hline Veillonella atypical & 20 & 2 \\
\hline \multicolumn{3}{|l|}{ Gram negative facultative anaerobic bacteria } \\
\hline Enterobacter aerogenes & 1 & 0.1 \\
\hline Morganella morganii & 1 & 0.1 \\
\hline Salmonella typhi & 1 & 0.1 \\
\hline Serratia marcescens & 1 & 0.1 \\
\hline Shigella flexneri & 1 & 0.1 \\
\hline Shigella sonnei & 2 & 0.2 \\
\hline Klebsiella sp HL1 & 3 & 0.3 \\
\hline Pantoea sp & 3 & 0.3 \\
\hline Klebsiella pneumoniae & 4 & 0.4 \\
\hline Enterobacter cancerogenus LMG 1693 & 10 & 1 \\
\hline Escherichia coli & 90 & 8.8 \\
\hline \multicolumn{3}{|l|}{ Gram positive anaerobic bacteria } \\
\hline Actinomyces sp oral clone СТ068 & 1 & 0.1 \\
\hline Clostridium irregularis & 1 & 0.1 \\
\hline Eubacterium halii & 1 & 0.1 \\
\hline Lactobacillus acidophilus johnsonii & 1 & 0.1 \\
\hline Ruminococcus obeum & 1 & 0.1 \\
\hline Clostridium leptum & 2 & 0.2 \\
\hline Clostridium methoxybenzovorans & 2 & 0.2 \\
\hline Clostridium ramosum & 2 & 0.2 \\
\hline Clostridium symbiosum & 2 & 0.2 \\
\hline Peptostreptococcus productus & 2 & 0.2 \\
\hline Clostridium indolis & 3 & 0.3 \\
\hline Clostridium sp & 6 & 0.6 \\
\hline Clostridium glycolicum & 8 & 0.8 \\
\hline Clostridium orbiscindens & 13 & 1.3 \\
\hline Clostridium nexile & 27 & 2.6 \\
\hline Butyrate producing bacterium L2-6 & 32 & 3.1 \\
\hline Ruminococcus gnavus & 52 & 5.1 \\
\hline Ruminococcus hansenii & 75 & 7.3 \\
\hline \multicolumn{3}{|l|}{ Gram positive facultative anaerobic bacteria } \\
\hline Staphylococcus epidermidis & 1 & 0.1 \\
\hline \multicolumn{3}{|l|}{ Gram positive aerotolerant anaerobic bacteria } \\
\hline Lactococcus lactis subsp cremoris & 1 & 0.1 \\
\hline Streptococcus intermedius & 1 & 0.1 \\
\hline Enterococcus faecium & 1 & 0.1 \\
\hline Lactococcus lactis subsp lactis IL1 & 2 & 0.2 \\
\hline Streptococcus sanguis & 2 & 0.2 \\
\hline Streptococcus anginosus & 8 & 0.8 \\
\hline Streptococcus mitis & 11 & 1.1 \\
\hline Streptococcus salivarius & 12 & 1.2 \\
\hline Streptococcus sp (different clones) & 153 & 15.0 \\
\hline Streptococcus parasanguis & 157 & 15.4 \\
\hline \multicolumn{3}{|l|}{ Uncultured bacteria } \\
\hline Uncultured bacteria (different clones) & 279 & 27.3 \\
\hline \multicolumn{3}{|c|}{$\begin{array}{l}\text { *Nomenclature according to Bergey's Manual of Determinative } \\
\text { Bacteriology (Holt, 1994). } \\
\text { tFull length 16S rDNA sequences from a total of } 1019 \text { clones from three } \\
\text { biopsies of patients with ulcerative colitis, Crohn's disease, and a normal } \\
\text { control using all bacteria primer sets. Specific bacteria were identified by } \\
\text { NCBI BLAST analysis using search results of at least } 97 \% \text { similarity (NCBI } \\
\text { BLAST, http://www.ncbi.nlm.nih.gov/). }\end{array}$} \\
\hline
\end{tabular}

\section{DISCUSSION}

The global composition of the intestinal bacterial microflora rather than the presence of single pathogens appears to be relevant for IBD pathogenesis and aetiology. Analysis of bacterial 16S rRNA genes, amplified directly from complex communities, provides an efficient strategy to explore the bacterial diversity of complex microflora..$^{39-41}$ In contrast with previous studies, we examined biopsy samples to determine the mucosa associated bacteria directly interacting with the host. 


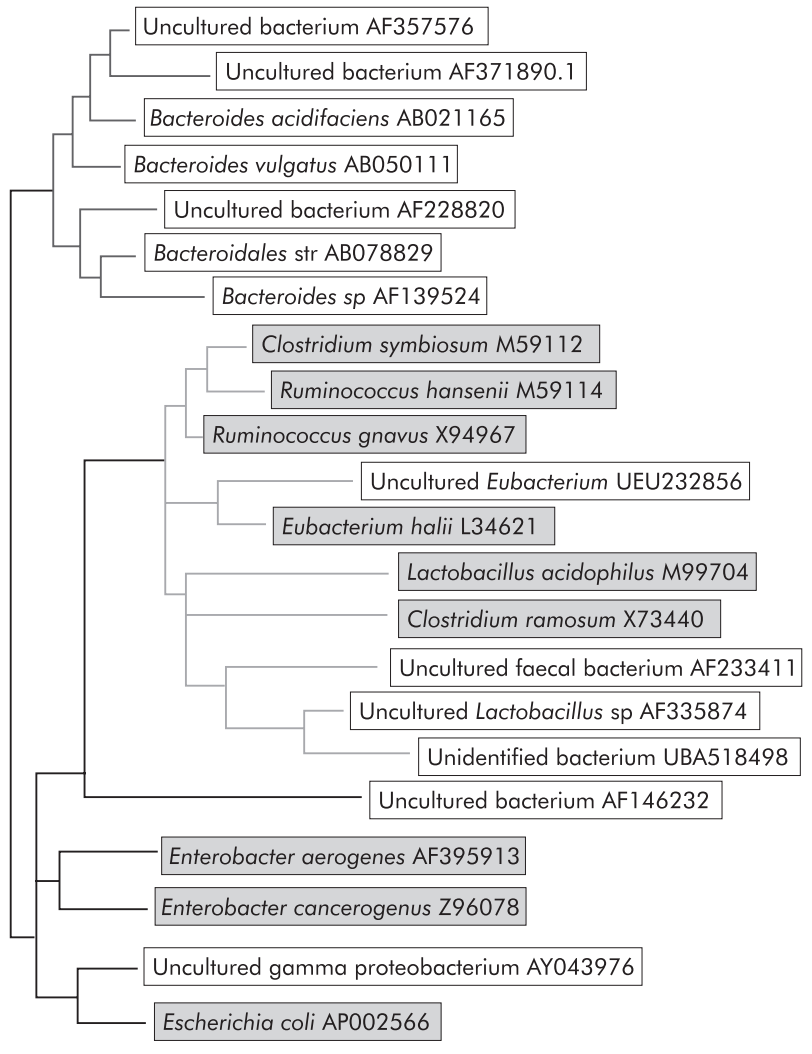

$15 \%$

Figure 4 Phylogenetic tree of the operational taxonomic units (OTUs) identified in the single strand conformation polymorphism (SSCP) profiles by the Band Matching algorithm. Fragments were identified by NCBI blast search (BLAST, http://www.ncbi.nlm.nih.gov/). The corresponding representative OTUs from the clone libraries (highlighted in grey) were inserted as benchmarks for phylogenetic orientation. The phylogenetic tree was built from sequence data of the SSCP profiles and the corresponding region (V4 and V5) of the sequences of the clone libraries with the ARB software package (http://www.arb-home.de/), using the parsimony algorithm and the Jukes-Cantor correction. ${ }^{37} 77$ Three clusters are defined by phylogenetic relationships: Bacteroides/ Prevotella group (cluster 1), Firmicutes phylum (cluster 2), and Enterobacteriaceae family (cluster 3).

To obtain an overall assessment of bacterial diversity, we generated full length 16S rDNA libraries of three sigma biopsies. Analysis of clone libraries (table 4) highlights the

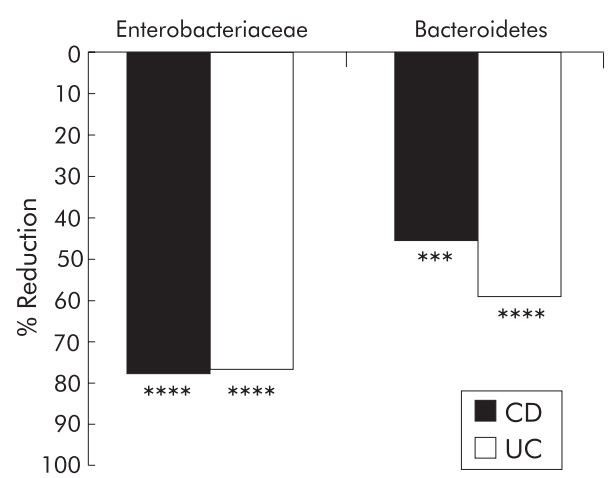

Figure 5 Reduction of Bacteroidetes and Enterobacteriaceae, as determined by real time polymerase chain reaction in patients with Crohn's disease (CD) and ulcerative colitis (UC). All results were statistically significant ( $\left.{ }^{* * *} p=0.003,{ }^{* * * *}<p<0.0001\right)$.

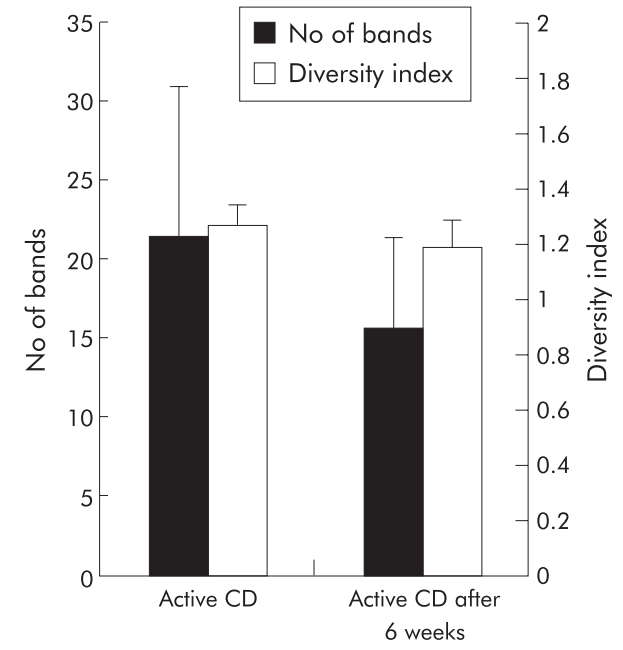

Figure 6 Comparison of the bacterial profiles of 10 patients with active Crohn's disease (CD) before and after a six week follow up. Bacterial diversity is indicated as number of bands (SD) and as diversity score (SD). Biodiversity was lower after six weeks but the results were not significant $(p=0.054)$.

enormous diversity of bacterial species in the mucosal flora. It should be noted however that the number of patients used for construction of the clone libraries and the technique itself are not appropriate for a comparison between groups and should serve only as a qualitative guide for the genetic fingerprinting experiments. In contrast with previous studies, bacterial diversity of the mucosa associated intestinal microflora was based on full length 16S rDNA sequences. The majority of the 83 clones belonged to the normal anaerobic microflora of the human gut. Interestingly, more than $30 \%$ of the signals represented novel or incompletely annotated species. Approximately 95\% of the OTUs found in stool samples could be assigned to three phylogenetic groups: ${ }^{67}$ the Bacteroides group, the Clostridium coccoides group, and the Clostridium leptum group. Interestingly, we detected no members of the Bacteroides group which usually account

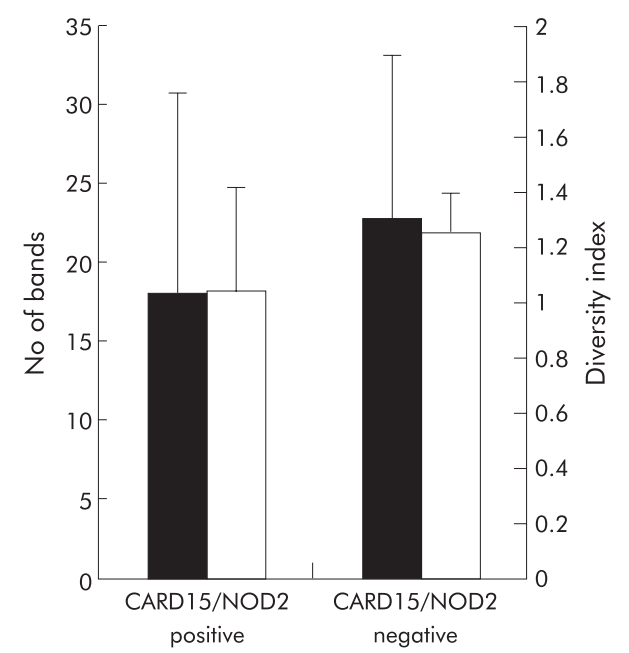

Figure 7 Correlation of bacterial diversity and CARD15/NOD2 status of patients with Crohn's disease (CD). Six of the 26 patients (30\%) tested CARD15/NOD2 positive (detection of at least one of the three major single nucleotide polymorphisms-SNP8, SNP12, and SNP13).

Diversity, indicated as number of bands and as weighted diversity score, was not significantly different in the CARD15/NOD2 positive group compared with wild-type patients $(p=0.063$ and $p=0.11$, respectively). 
for $50-90 \%$ of the anaerobic faecal microflora. This is in line with findings of other studies suggesting that the mucosa associated microflora contains only small numbers of bacteria of the Bacteroides/Prevotella group. ${ }^{44^{51}}$ Detection of these species in the larger SSCP experiment microflora represents the interindividual variability of the bacterial microflora of a high number of patients compared with the cloning experiment.

Generation of clone libraries is very laborious and expensive, and thus SSCP analysis was performed as a simple and reliable molecular technique to examine the molecular epidemiology of the microbial composition in a larger number of patients. ${ }^{52}{ }^{53}$ Cluster analysis of the bacterial profiles revealed distinct clustering of non-inflammatory controls that separated from a mixed cluster of patients with CD and UC (fig 1). Diversity in IBD was reduced in comparison with controls, with a trend towards greater reduction of diversity in UC (not statistically significant in comparison with CD). Patients with inflammatory diseases and diarrhoea showed a complex pattern with high interindividual variability. Bacterial diversity was comparable with that of non-inflammatory controls and significantly higher than that of $\mathrm{CD}$ and UC patients, suggesting that reduced bacterial diversity in IBD is a disease specific feature. The phenomenon of decreased bacterial diversity of the intestinal microflora obtained from stool samples in IBD patients has been discussed previously, based on culture dependent microbiological techniques. ${ }^{9}$ A recent study compared the faecal microflora of healthy controls and CD patients using a similar approach. ${ }^{46}$ The authors found no differences in bacterial diversity between controls and CD patients. This lack of significance may be due to differences in the mucosal and faecal microflora. ${ }^{45} 56$ The faecal microflora is reported to be host specific and stable over time. ${ }^{43}$ To rule out the fact that alterations of the mucosa associated microflora demonstrated in this study are attributed to transient factors, the bacterial profiles of 10 patients with active CD were investigated after a period of six weeks. Biopsies were taken from the same location, and treatment had not been changed during that period. Comparison of the bacterial profiles revealed a low diversity of the mucosa associated microflora; thus the observed effects seem to be stable over time.

Most of the bacterial species found to be different between non-inflammatory controls and IBD patients belonged to the normal anaerobic intestinal microflora. Quantitative real time analysis confirmed a significant reduction of two major groups of anaerobic bacteria. Bacteroides species are part of the indigenous intestinal microflora. In faecal samples, up to $10^{10}$ cells/g stool relate to different Bacteroides bacteria, thus accounting for approximately $30 \%$ of the total number of cells. In contrast, Bacteroides were found only sporadically in mucosal biopsies. ${ }^{4451}$ Some members of the Bacteroides/ Prevotella group, in particular Bacteroides vulgatus, were previously reported to have proinflammatory effects in several animal models of IBD. ${ }^{18-20}{ }^{68}$ However, in a model of IL-10 deficient mice, Bacteroides vulgatus could not induce colitis. $^{21} 22$ Some culture studies have shown a possible increase in faecal Bacteroides, especially Bacteroides fragilis, in $\mathrm{CD}^{69}{ }^{70}$ while a recent study observed a decrease in the relative proportions of the Bacteroides group..$^{46}$ Lactobacillus and Eubacterium species belong to the Firmicutes bacteria and have been shown to be frequent and stable members of both the normal faecal and mucosa associated bacterial community. ${ }^{45} 477172$ Furthermore, animal models and clinical studies attribute beneficial effects to orally administered Lactobacillus bacteria in maintenance of remission in UC and CD. ${ }^{26-31}$ One of the species excised from the SSCP gel showed a close phylogenetic relationship to the Enterobacteriaceae group.
Enterobacteriaceae compose a homogenous group of closely related intestinal bacteria. Most of the species in this group are representatives of the normal intestinal microflora, such as Escherichia coli and Enterobacter. Other members of this group are pathogens inducing severe infectious diarrhoea, such as Shigella, Salmonella, and Yersinia species. Some strains of Escherichia coli have been suspected to play a role in the aetiology of IBD. ${ }^{73}$

CARD15/NOD2 is a member of the NOD gene family, and has a role in mediation of inflammatory responses to bacterial antigens. CARD15/NOD2 expression is upregulated by proinflammatory cytokines such as tumour necrosis factor $\alpha$, as demonstrated for inflammatory bowel disease. ${ }^{74} \mathrm{~A}$ recent study showed that CARD15/NOD2 functions as a defensive factor against intracellular bacteria in intraepithelial cells. ${ }^{76}$ To compare the bacterial microflora between CARD15/NOD2 positive and non-affected patients, all CD patients were checked for CARD15/NOD2 mutations by SNP genotyping. We found no significant differences in bacterial diversity or bands between the two groups. CARD15/NOD2 expression is assumed to have a key function in the recognition of bacterial antigens but this effect appears to play a role in the early phase of the innate immune response to single intraepithelial pathogens. We hypothesise that alteration of the bacterial microflora in mucosal inflammation reflects a metabolic imbalance of the complex microbial ecosystem with severe consequences for the mucosal barrier rather than disrupted defence to single microorganisms.

In this study, we demonstrated that mucosal inflammation in IBD was associated with loss of normal anaerobic bacteria and identified a number of specific taxa. These findings provide additional evidence for a role of luminal bacteria in the pathogenesis of IBD. Further studies are needed to determine to what extent these changes are primary or secondary to an altered mucosal microenvironment. Longitudinal studies may help to explain the aetiological mechanisms of alterations of the bacterial microflora and to assess the impact of external factors.

\section{ACKNOWLEDGEMENTS}

This work was supported by grants from the German National Genome Research Network (NGFN), the German Human Genome Project (DHGP), the Competence Network Inflammatory Bowel Disease (all funded by the BMBF), the DFG (SFB415), the Crohn's and Colitis Foundation of America (CCFA), and the EU (EU QLG2CT-2001-02161). We thank Friedrich von Wintzingerode for his contributions to the cloning experiments. We gratefully acknowledge Meike Barche, Nadine Teepe, Theresa Nahmuth, Annette Krüger, and Agnes Waliczek for their technical assistance.

\section{Authors' affiliations \\ S J Ott*, M Musfeldt*, J Hampe, O Brant, U R Fölsch, S Schreiber, Department of General Internal Medicine, University Hospital Schleswig- Holstein, Campus Kiel, Germany \\ D F Wenderoth, K N Timmis, German Research Center for Biotechnology (GBF), Department of Microbiology, Braunschweig, Germany}

*S J OHt and M Musfeldt contributed equally to this study

\section{REFERENCES}

1 Hooper LV, Wong MH, Thelin A, et al. Molecular analysis of commensal hostmicrobial relationships in the intestine. Science 2001;291:881-4.

2 Hooper LV, Gordon J. Commensal host-bacterial relationships in the gut. Science 2001;292:1115-18.

3 Madsen KL, Doyle JS, Jewell LD, et al. Lactobacillus species prevents colitis in interleukin 10 gene-deficient mice. Gastroenterology 1999; 116:1 107-14.

4 Hampe J, Cuthbert A, Croucher PJ, et al. Association between insertion mutation in NOD2 gene and Crohn's disease in German and British populations. Lancet 2001;357:1925-8. 
5 Hugot JP, Chamaillard M, Zouali $\mathrm{H}$, et al. Association of NOD2 leucine-rich repeat variants with susceptibility to Crohn's disease. Nature 2001;411:599-603.

6 Ogura Y, Bonen DK, Inohara N, et al. A frameshift mutation in NOD2 associated with susceptibility to Crohn's disease. Nature 2001;411:603-6.

7 Tannock GW. Analysis of the intestinal microflora: a renaissance. Antonie Van Leeuwenhoek 1999;76:265-78.

8 Shanahan F. Crohn's disease. Lancet 2002;359:62-9.

9 Sartor RB. Enteric microflora in IBD: pathogens or commensals? Inflamm Bowel Dis 1997;3:230-5.

10 Guarner F, Malagelada JR. Gut flora in health and disease. Lancet 2003;361:512-9.

11 Chiodini RJ, Van Kruiningen HJ, Thayer WR, et al. Possible role of mycobacteria in inflammatory bowel disease. I. An unclassified Mycobacterium species isolated from patients with Crohn's disease. Dig Dis Sci 1984;29:1073-9.

12 Coloe PJ, Wilkes CR, Lightfoot D. Isolation of Mycobacterium paratuberculosis in Crohn's disease. Aust Microbiol 1986;7:188A.

13 Ryan P, Bennett MW, Aarons S, et al. PCR detection of Mycobacterium paratuberculosis in Crohn's disease granulomas isolated by laser capture microdissection. Gut 2002;51:665-70.

14 Liu $Y$, van Kruiningen $H J$, West $A B$, et al. Immunocytochemical evidence of Listeria, Escherichia coli, and Streptococcus antigens in Crohn's disease. Gastroenterology 1995;108:1396-404.

15 McOrist S, Jasni S, Mackie RA, et al. Reproduction of porcine proliferative enteropathy with pure cultures of ileal symbiont intracellularis. Infect Immun 1993;61:4286-92.

16 Thayer WR ir, Coutu JA, Chiodini RJ, et al. Possible role of mycobacteria in inflammatory bowel disease. II. Mycobacterial antibodies in Crohn's disease. Dig Dis Sci 1984;29:1080-5.

17 Chiodini RJ, Van Kruiningen HJ, Merkal RS, et al. Characteristics of an unclassified Mycobacterium species isolated from patients with Crohn's disease. J Clin Microbiol 1984;20:966-71.

18 Onderdonk AB, Franklin ML, Cisneros RL. Production of experimental ulcerative colitis in gnotobiotic guinea pigs with simplified microflora. Infect Immun 1981;32:225-31.

19 Rath HC, Herfarth HH, Ikeda JS, et al. Normal luminal bacteria, especially Bacteroides species, mediate chronic colitis, gastritis, and arthritis in HLAB27/human beta2 microglobulin transgenic rats. J Clin Invest 1996;98:945-53.

20 Rath HC, Wilson KH, Sartor RB. Differential induction of colitis and gastritis in HLA-B27 transgenic rats selectively colonized with Bacteroides vulgatus or Escherichia coli. Infect Immun 1999;67:2969-74.

21 Waidmann M, Allemand Y, Lehmann J, et al. Microflora reactive IL10 producing regulatory T cells are present in the colon of IL2 deficient mice but lack efficacious inhibition of IFN-gamma and TNF-alpha production. Gut 2002;50:170-9.

22 Sellon RK, Tonkonogy S, Schultz M, et al. Resident enteric bacteria are necessary for development of spontaneous colitis and immune system activation in interleukin-10-deficient mice. Infect Immun 1998;66:5224-31.

23 Sartor RB, Rath HC, Sellon RK. Microbial factors in chronic intestinal inflammation. Curr Opin Gastroenterol 1996;12:327-33.

24 Rutgeerts $\mathrm{P}$, Geboes K, Peeters M, et al. Effect of faecal stream diversion on recurrence of Crohn's disease in the neoterminal ileum. Lance 1991:338:771-4.

25 Sandborn WJ, Landers CJ, Tremaine WJ, ef al. Antineutrophil cytoplasmic antibody correlates with chronic pouchitis after ileal pouch-anal anastomosis. Am J Gastroenterol 1995;90:740-7.

26 Kruis W, Schutz E, Fric $P$, et al. Double-blind comparison of an oral Escherichia coli preparation and mesalazine in maintaining remission of ulcerative colitis. Aliment Pharmacol Ther 1997;11:853-8.

27 Malchow HA. Crohn's disease and Escherichia coli. A new approach in therapy to maintain remission of colonic Crohn's disease? J Clin Gastroenterol 1997;25:653-8.

28 Rembacken BJ, Snelling AM, Hawkey PM, et al. Non-pathogenic Escherichia coli versus mesalazine for the treatment of ulcerative colitis: a randomised trial. Lancet 1999;354:635-9.

29 Venturi A, Gionchetti P, Rizzello F, et al. Impact on the composition of the faecal flora by a new probiotic preparation: preliminary data on maintenance treatment of patients with ulcerative colitis. Aliment Pharmacol Ther 1999;13:1103-8.

30 Steidler L, Hans W, Schotte L, et al. Treatment of murine colitis by Lactococcus lactis secreting interleukin-10. Science 2000;289:1352-5.

31 Gionchetti P, Rizzello F, Venturi A, et al. Oral bacteriotherapy as maintenance treatment in patients with chronic pouchitis: a double-blind, placebocontrolled trial. Gastroenterology 2000;119:305-9.

32 Simon GL, Gorbach SL. Intestinal flora in health and disease. Gastroenterology 1984;86:174-93.

33 Tannock GW. Molecular assessment of intestinal microflora. Am J Clin Nutr 2001;73:S410-14.

34 Tannock GW. Molecular methods for exploring the intestinal ecosystem. Br J Nutr 2002;87:S199-201.

35 Langendijk $P$, Schut $F$, Jansen $G$, et al. Quantitative fluorescence in situ hybridization of Bifidobacterium spp. with genus-specific $16 \mathrm{~S}$ rRNA-targeted probes and application in fecal samples. Appl Environ Microbiol 1995;61:3069-75.

36 Wilson K, Blitchington R. Human colonic biota studied by ribosomal DNA sequence analysis. Appl Environ Microbiol 1996;62:2273-8.
37 Hugenholtz P, Goebel BM, Pace NR. Impact of culture-independent studies on the emerging phylogenetic view of bacterial diversity. J Bacteriol 1998;180:4765-74.

38 McFarlene G, Gibson G. Metabolic activities of the normal colonic microflora. In: Gibson S, ed. Human health: contribution of microorganisms. Frankfurt: Springer, 1994:17-38.

39 Woese CR, Fox GE. Phylogenetic structure of the prokaryotic domain: the primary kingdoms. Proc Natl Acad Sci U S A 1977;74:5088-90.

40 Amann RI, Ludwig W, Schleifer KH. Phylogenetic identification and in situ detection of individual microbial cells without cultivation. Microbiol Rev 1995;59:143-69.

41 Pace N. A molecular view of microbial diversity and the biosphere. Science 1997;276:734-40

42 Zheng D, Alm E, Stahl D, et al. Characterization of universal small-subunit rRNA hybridization probes for quantitative molecular microbial ecology studies. Appl Environ Microbiol 1996;62:4504-13.

43 Zoetendal EG, Akkermans ADL, De Vos WM. Temperature gradient gel electrophoresis analysis of 16S rRNA from human fecal samples reveals stable and host-specific communities of active bacteria. Appl Environ Microbiol 1998;64:3854-9

44 Swidsinski A, Ladhoff A, Pernthaler A, et al. Mucosal flora in inflammatory bowel disease. Gastroenterology 2002;122:44-54.

45 Zoetendal EG, von Wright A, Vilpponen-Salmela T, et al. Mucosa-associated bacteria in the human gastrointestinal tract are uniformly distributed along the colon and differ from the community recovered from feces. Appl Environ Microbiol 2002;68:3401-7.

46 Seksik P, Rigottier-Gois L, Gramet G, et al. Alterations of dominant fecal bacterial groups in patients with Crohn's disease of the colon. Gut 2003;52:237-42.

47 Walter J, Hertel C, Tannock GW, et al. Detection of Lactobacillus, Pediococcus, Leuconostoc, and Weissella species in human feces by using group-specific PCR primers and denaturing gradient gel electrophoresis. Appl Environ Microbiol 2001;67:2578-85

48 Tannock GW. The bifidobacterial and Lactobacillus microflora of humans. Clin Rev Allergy Immunol 2002;22:231-53.

49 Dore J, Sghir A, Hannequart-Gramet G, et al. Design and evaluation of a 16S rRNA-targeted oligonucleotide probe for specific detection and quantitation of human faecal Bacteroides populations. Syst Appl Microbiol 1998;21:65-71.

50 Zoetendal EG, Ben-Amor K, Harmsen HJ, et al. Quantification of uncultured ruminococcus obeum-like bacteria in human fecal samples by fluorescent in situ hybridization and flow cytometry using 16S rRNA-targeted probes. Appl Environ Microbiol 2002;68:4225-32.

51 Kleessen B, Kroesen AJ, Buhr HJ, et al. Mucosal and invading bacteria in patients with inflammatory bowel disease compared with controls. Scand J Gastroenterol 2002;37:1034-41.

52 Schwieger F, Tebbe CC. A new approach to utilize PCR-single-strandconformation polymorphism for 16S rRNA gene-based microbial community analysis. Appl Environ Microbiol 1998:64:4870-6.

53 Tebbe CC, Schmalenberger A, Peters S, et al. Single-strand conformation polymorphism (SSCP) for microbial community analysis. In: Rochelle PA, ed. Environmental molecular microbiology: protocols and applications. Wymondham, UK: Horizon Scientific Press, 2001:161-74.

54 Valinsky L, Della Vedova G, Jiang T, et al. Oligonucleotide fingerprinting of rRNA genes for analysis of fungal community composition. Appl Environ Microbiol 2002;68:5999-6004

55 Valinsky L, Della Vedova G, Scupham AJ, et al. Analysis of bacterial community composition by oligonucleotide fingerprinting of rRNA genes. Appl Environ Microbiol 2002;68:3243-50.

56 Bignell DE, Oskarsson H, Anderson JM. Distribution and abundance of bacteria in the gut of a soil-feeding termite Procutiermes aburiensis (Termitidae, Termitinae). J Gen Microbiol 1980;117:393-403.

57 Malchow H, Ewe K, Brandes JW, et al. European Cooperative Crohn's Disease Study (ECCDS): results of drug treatment. Gastroenterology 1984;86:249-66.

58 Chapman RW, Selby WS, Jewell DP. Controlled trial of intravenous metronidazole as an adjunct to corticosteroids in severe ulcerative colitis. Gut 1986:27:1210-12

59 Wenderoth DF, Ferslev B, Macarri G, et al. Leitbakteria of microbial biofilm communities causing occlusion of biliary stents. Environ Microbiol 2003;5:859-66.

60 Shannon CE, Weaver W. Mathematical theory of communication. Illinois: University of Illinois Press, 1963.

61 Wenderoth DF, Reber HH. Correlation between structural diversity and catabolic versatility of metal-affected prototrophic bacteria in soil. Soil Biol Biochem 1999:31:345-52.

62 Hane BG, Jager K, Drexler HG. The Pearson product-moment correlation coefficient is better suited for identification of DNA fingerprint profiles than band matching algorithms. Electrophoresis 1993;14:967-72.

63 Lyons SR, Griffen AL, Leys EJ. Quantitative real-time PCR for porphyromonas gingivalis and total bacteria. J Clin Microbiol 2000;38:2362-5.

64 Hampe J, Shaw SH, Saiz R, et al. Linkage of inflammatory bowel disease to human chromosome 6p. Am J Hum Genet 1999;65:1647-55.

65 Hampe J, Wollstein A, Lu T, et al. An integrated database for Taqman based high throughput SNP genotyping. Bioinformatics 2001;17:654-5.

66 Hampe J, Grebe J, Nikolaus S, et al. Association of NOD2 (CARD 15) genotype with clinical course of Crohn's disease: a cohort study. Lancet 2002;359:1661-5

67 Suau A, Bonnet R, Sutren M, et al. Direct analysis of genes encoding $16 \mathrm{~S}$ rRNA from complex communities reveals many novel molecular species within the human gut. Appl Environ Microbiol 1999;65:4799-807. 
68 Rath HC, Ikeda JS, Linde HJ, et al. Varying cecal bacterial loads influences colitis and gastritis in HLA-B27 transgenic rats. Gastroenterology 1999;116:310-19.

69 Ruseler-van Embden JG, Both-Patoir HC. Anaerobic gram-negative faecal flora in patients with Crohn's disease and healthy subjects. Antonie Van Leeuwenhoek 1983;49:125-32.

70 Giaffer MH, Holdsworth CD, Duerden BI. The assessment of faecal flora in patients with inflammatory bowel disease by a simplified bacteriological technique. J Med Microbiol 1991;35:238-43.

71 Walter J, Tannock GW, Tilsala-Timisjarvi A, et al. Detection and identification of gastrointestinal Lactobacillus species by using denaturing gradient gel electrophoresis and species-specific PCR primers. Appl Environ Microbiol 2000;66:297-303.

72 Tannock GW, Tilsala-Timisjarvi A, Rodtong S, et al. Identification of Lactobacillus isolates from the gastrointestinal tract, silage, and yoghurt by 16S-23S rRNA gene intergenic spacer region sequence comparisons. Appl Environ Microbiol 1999;65:4264-7.

73 Sartor RB. Microbial factors in the pathogenesis of Crohn's disease, ulcerative colitis, and experimental intestinal inflammation. In: Kirshner JB, ed. Inflammatory bowel disease, 5th edn. Philadelphia: WB Saunders, 2000:153-78.
74 Gutierrez O Pipaon C, Inohara N, et al Induction of Nod2 in myelomonocytic and intestinal epithelial cells via nuclear factor-kappa B activation. J Biol Chem 2002;277:41701-5.

75 Rosenstiel P, Fantini M, Brautigam K, et al. TNF-alpha and IFN-gamma regulate the expression of the NOD2 (CARD15) gene in human intestinal epithelial cells. Gastroenterology 2003;124:1001-9.

76 Hisamatsu T, Suzuki M, Reinecker HC, et al. CARD15/NOD2 functions as an antibacterial factor in human intestinal epithelial cells. Gastroenterology 2003; 124:993-1000.

77 Takahashi K, Nei M. Efficiencies of fast algorithms of phylogenetic inference under the criteria of maximum parsimony, minimum evolution, and maximum likelihood when a large number of sequences are used. Mol Biol Evol 2000;17:1251-8.

78 von Wintzingerode $F$, Landt $O$, Ehrlich $A$, et al. Peptide nucleic acid-mediated PCR clamping a useful supplement in the determination of microbial diversity. Appl Environ Microbiol 2000;66:549-57

79 Guttman DS, Charlesworth D. An X-linked gene with a degenerate Y-linked homologue in a dioecious plant. Nature 1998;393:263-6.

80 Sghir A, Gramet G, Suau A, et al. Quantification of bacterial groups within human fecal flora by oligonucleotide probe hybridization. Appl Environ Microbiol 2000;66:2263-6. 